\title{
A geometria barroca do destino
}

//I/I//I/I/I/I/I/I/I! Ismail Xavier

1. Professor livre-docente no Programa de Pós-Graduação em Meios e Processos Audiovisuais e no Departamento de Cinema, Rádio e Televisão da Escola de Comunicações e Artes da Universidade de São Paulo. E-mail: i-xavier@uol.com.br 
Resumo

Análise da leitura que o filme Lavoura arcaica (2001), de Luiz Fernando Carvalho, faz do romance homônimo de Raduan Nassar (1975), com ênfase nas diferenças que se produzem na condução de um projeto marcado pela sintonia entre escritor e cineasta. No filme, há a forte presença da voz over do narrador, que transpõe passagens do texto de Raduan. No romance, a palavra é soberana; no cinema, ela deve interagir com a mise-en-scène; imagem e som compõem uma nova dinâmica, que define a originalidade das escolhas do cineasta e sua concepção da tragédia familiar.

\section{Palavras-chave}

cinema, literatura, imagem e som, narrador, transposição

\section{Abstract}

Analysis of the reading that the film Lavoura arcaica (2001), by Luiz Fernando Carvalho, makes of the novel by Raduan Nassar (1975), with emphasis on the differences that arise in conducting a project marked by the line between writer and filmmaker. In the film, there is the strong presence of the narrator's voice "over", which transposes the passages of the Raduan's text. In the novel, the word is sovereign, in the film, it must interact with the mise-en-scène, image and sound make up a new dynamic, which defines the originality of the filmmaker's choices and their conception of family tragedy.

\section{Key-words}

cinema, literature, image and sound, narrator, transposition 


\section{Filme e romance: a sintonia na diferença}

Ao filmar Lavoura arcaica, Luiz Fernando Carvalho concebeu a relação entre som e imagem, narrador e cena, de modo a buscar uma sintonia com as opções de Raduan Nassar em seu livro (NASSAR, 1975). Assim, compõe com rigor a sequência de abertura que traduz as primeiras páginas, quando encontramos André a se masturbar no quarto de pensão, numa solidão interrompida pela chegada do irmão mais velho, que veio buscá-lo em nome da família. A longa conversa no reencontro entre os irmãos é o solo dramático a partir do qual se compõem os flashbacks que trazem a experiência do protagonista antes de seu abandono da casa, dentro de uma organização do tempo que se ajusta ao andamento do romance.

As simetrias marcadas pela repetição do texto encontram, no filme, sua transposição visual. Não raro, o livro retoma um episódio passado ou uma associação já feita, sugerindo um tempo circular que, no entanto, se quebra a certa altura, pois as palavras assumem um novo torneio para registrar a diferença, de modo a marcar o avanço inexorável que faz o impulso de repetição confrontar a passagem irreversível do tempo. Afinal, a narrativa traz o fato irremediável que marca a transposição de fronteira, a cópula de André e sua irmã, Ana, o incesto que abala a ordem e torna impossível a simples repetição pela qual as duas versões da festa familiar ao ar livre pudessem se espelhar em total harmonia. Resulta que uma é felicidade e união; a outra, ao final, é crise e dissolução.

No romance, as palavras de André, o narrador, são soberanas na instituição de sua própria história, na recapitulação do seu pas- 
sado. No filme, a fala em primeira pessoa se incorpora como voz over, locução que, embora afirme seu tempo e lugar, se instala num ambiente visual e sonoro que oferece a cena visível. A voz narra, comenta, afirma um estilo, mas deve interagir com outros canais de expressão, de modo que a sobreposição dos tempos se faça também por modulações de luz, movimentos de câmera, inserções sonoras. A repetição de motivos se trabalha aí no campo da imagem, tal como se vê nos reiterados planos dos pés de André em contato com o solo, seja no prazer do mergulho e do atrito com as folhas e com a terra, ou com a palha da casa velha, seja no passo tenso da caminhada noturna que o levou de casa, seja no quarto de pensão a que Pedro chega para chamá-lo de volta. E trabalha-se também na modulação dos olhares de André quando deitado: há imagem do teto e da luminária modesta no quarto da pensão, há o sorriso da mãe lá na infância a adentrar no quarto para vir afagá-lo em meio aos lençóis, e há a reiteração do céu iluminado e da copa das árvores, situações em que o filme repõe o novelo de metáforas do livro. A luz solar se conecta ao tempo da infância, momento de promessa, em oposição às sombras do quarto da pensão, espaço da angústia e das tensões, no qual a câmera "epidérmica" e a luz com toque expressionista desenham os seus olhos como "caroços repulsivos", traduzindo o texto.

O espaço de convergência entre o filme e o romance revela uma densidade de estilo na composição de imagem e som que gerou o entusiasmo da crítica. ${ }^{2}$ Uma feliz adaptação definiu a transposição do cerimonial e de figuras de estilo, mas não poderia significar uma identidade absoluta de tom e sentido, dada a polarização do drama trazida pela composição das cenas e pela forte presença de uma partitura musical que acentua, de começo a fim, a carga de afetos associados a uma tradição cultural que habita o núcleo familiar e ganha especial ressonância no filme. Luiz Fernando Carvalho privilegia intensidades, marca a inclinação do seu cinema em direção à ópera, com particular exploração dramática das texturas do corpo, dos objetos e da natureza.

Desde seu primeiro plano, a cena de abertura se compõe numa chave de desconforto mais incisiva do que a suscitada pela leitura do livro. O movimento de câmera percorre uma zona obscura, de onde emergem as dobras de um lençol sombreadas na cama vazia (distante, portanto, do lençol branco e luminoso que veremos nas
2. Como referência à recepção entusiasta da crítica, lembro alguns artigos, com as inevitáveis omissões, publicados nos jornais de Rio, São Paulo e Brasília, por Joel Birman, Carlos Alberto de Mattos, José Geraldo Couto, Tiago Mata Machado, Arnaldo Carrilho, Ubiratan Brasil e Cláudio Marques, entre outros. Para uma antologia de textos, ver o caderno que acompanha o DVD do filme na caixa lançada pelas edições Palmira, 2006. Ver ainda Maurício Hirata, "O excesso de luz de Lavoura arcaica", em Sinopse n. 10, 2004, p. 16-25; e Cléber Eduardo, "Eu é um outro: variações da narração em primeira pessoa”, em Daniel Caetano (Org.), ContracampoCinema Brasileiro 1995-2005: ensaios sobre uma década (Rio de Janeiro, Azougue Editorial, 2005), p. 137-151. 
cenas da infância); chegamos ao rosto de André deitado no chão, com parte do corpo debaixo da cama. Um misto de excitação e agonia se expressa na respiração ofegante, na protuberância dos ossos do torso e da face, na boca aberta. Muito próxima, a lente especial não economiza os desfoques para descolar o fragmento visível do restante do corpo. Há energia, agitação, mas tudo parece no limite do humano, uma crispação em sintonia com o ruído do trem que invade a cena e se avoluma seguindo o ritmo da sua masturbação. Completado o ciclo, o corpo se aquieta, e o barulho que maquinava a excitação se dissolve. O rosto deformado de André preenche a tela. O torpor e o silêncio são quebrados pelas batidas fortes na porta. Em seu apelo inesperado, Pedro já se anuncia como figura do desagrado, hipótese que logo se confirma no encontro dos irmãos na penumbra. O "Nós te amamos muito" é logo seguido da fala impositiva: "Abotoe a camisa, André". Antes que ele cumpra o determinado, saltamos para a evocação luminosa da infância.

Nessa abertura, o desconforto se assenta na aspereza de som e imagem, composição que produz um impacto dramático algo distinto do que, a partir da mesma situação, sentimos na leitura do romance. Este faz menção ao desespero, mas o lapida de outras formas, sem o grito interior que se vocaliza no trem e que, em outras sequências, encontrará novas sonoridades - que, em chave lírica ou dramática, compõem a diferença a partir do horizonte comum de filme e livro. Com frequência, um movimento mais ondulado do texto encontra tradução mais cortante, como nessa abertura em que deformidade e estranheza tornam mais agudo o contraste entre o encontro na pensão e a leveza das cenas da infância, das quais emergem o embalo sentimental da música, as expansões da corrida dos meninos. O movimento presente das imagens compõe uma alegria de vida que se projeta no passado quando o tom lírico-evocativo da locução em voz over nos faz ouvir, pela primeira vez, o texto de Raduan. Não demora, e o novo timbre da voz e da peça musical (não há ruídos) nos leva ao corpo de André deitado na mata, coberto de folhas, a esfregar os pés na cama natural em que embala seus devaneios, numa tonalidade em tudo oposta à da figura convulsa debaixo da cama. Era o tempo suave da fazenda, do senso de abrigo que favorecia a preguiça, do coro das vozes protetoras enquanto ele sonhava sob a luz na copa das árvores. Era o impulso de alçar voo, descortinar um mundo, longe das tensões que, mais tarde, o desgar- 
rado enfrentou ao inventar uma relação peculiar entre a natureza e a lei moral, contra o sermão do pai.

Tal círculo solar da infância é logo dissolvido pela voz do protagonista-narrador que evoca, de forma afetuosa, o discurso do pai sobre os olhos como "candeia do corpo". "Se eles eram bons é porque o corpo tinha luz, e se os olhos não eram limpos é que eles revelavam um corpo tenebroso.” Recolhe-se aí a tradição que sempre celebrou os olhos como "janela da alma”, ideia muito cedo assimilada no século XX pelos críticos de cinema em seu elogio à então nova arte, e sugere-se aí um critério de estilo ligado aos sentimentos e aos humores, não propriamente um critério de verdade.

Em cima dessa citação do pai, voltamos a André que recebe Pedro na pensão, a camisa abotoada. Pedro quer abrir tudo, iluminar o quarto (“a veneziana está fechada”). André sai da frente do espelho em que se examinava como que para se refazer do momento em que a narrativa se pôs em marcha já convulsa, a nos fazer estranhar sua figura à deriva no canto do assoalho, nesse fundo do poço que, aprenderemos, é o ponto de inflexão em sua desventura vivida sem projeto, sem mesmo um efetivo interesse pelo mundo, espécie de purgatório em que mergulhou ao abandonar a família.

Aberta a veneziana, a luz inunda o quarto; no branco dessa luz nada mais se diferencia. Dessa figura da claridade em excesso emerge o letreiro - Lavoura arcaica - impregnado de uma conotação já inserida no jogo de oposições levado até o fim, quando a tela preta será o pano de fundo para as letras brancas e estaremos ouvindo as palavras do pai proferidas no epílogo do livro.

O texto de Raduan imprime uma cadência hipnótica à narrativa, faz potente o seu fluxo de associações em que a sensualidade e a opinião, o relato e a imprecação se expõem como um ritual que persiste em sua unidade, até mesmo quando é intenso o drama, o confronto intersubjetivo que envolve André, seu pai, seu irmão e sua irmã. Há uma ordem feita de períodos longos e repetições que compõem a atmosfera apta a absorver o contraste entre os momentos dramáticos e os de evocações serenas, vindas de um André narrador já distante. No filme, a configuração mais heterogênea dos meios de expressão traz sempre o risco de esgarçar o tecido, de modo a diluir o que no romance é densidade e coesão. Tal risco, Luiz Fernando o superou pela adoção de um estilo que reconhece a diferença das matérias. Mais propensa a experiências de choque, a 
sua montagem assume caminhos próprios na busca de um efeito de unidade. Se há passagens em que o filme acompanha o livro na cadência das associações verbais e imagéticas, a diferença é nítida nas sequências de montagem rápida, como acontece no momento "gótico" da conversa em que André grita para Pedro ("Sou epilético"), e o filme figura a sua autoimagem de maldito apoiada nos flashes de olhares e palavras acusatórias, uma histeria sonora e visual.

Há aspectos de fatura que trazem para Lavoura arcaica uma feição clássica: a exposição de motivos, a continuidade dramática, a tradução de certas metáforas do livro pela montagem. No entanto, seus traços de estilo afirmam o cinema moderno: na duração da cena, no andamento da fala, na impostação dos gestos tensos, com notável articulação entre a cena visível e a narração em voz over. Essa montagem vertical envolve cotejos em que a experiência do tempo se faz complexa, sem ferir o senso forte de uma teleologia, uma ordem das coisas que o jovem André intui, mas que, em sua rebeldia, não aceita, vivendo momentos de tensão aguda que o outro André, o narrador invisível, parece ter superado em sua evocação reconciliada, própria a um momento já posterior - a anagnorisis (o reconhecimento) - , no curso da experiência trágica de que foi protagonista, mas não de todo herói, como se verá.

\section{As duas vozes de André: o conflito e a reconciliação}

3. Refiro-me à situação dramática e às coordenadas de espaço e tempo que definem a condição a partir da qual o narrador faz o retrospecto. Ver KOZLOFF, 1988, p. 50.
No romance, a "situação épica"3 do narrador permanece indefinida, restando a premissa de que ele está num futuro não imediato face ao ocorrido. Há a fala do André que vive a experiência, está "em cena" a cada atualização do passado, e o discurso do André que narra à distância, numa modulação de tons que não fere a unidade do texto - todo ele sancionado pelo seu nome, embora a diferença entre o ato de viver o drama e o de evocá-lo post-factum problematize a continuidade-identidade desse "eu" como foco da enunciação.

Há um dialogismo de fundo, próprio ao romance como gênero, pelo qual se diz que são múltiplas as vozes (valores, perspectivas, sujeitos) que ganham expressão direta ou indireta na narrativa, mesmo quando a fatura indica uma única voz a conduzir o relato. Nesse particular, das questões presentes na leitura do livro, trago aqui a que terá mais incidência na apreciação do filme e que envolve a 
relação entre os dois Andrés.

O narrador, pelos vocábulos e pela sintaxe, dá um tom solene ao cotidiano, consagra o mundo dos sentidos e sugere a contaminação recíproca dos opostos, tudo conforme uma visão assumida desde a adolescência. Nesse sentido, torna estilo de exposição uma sensibilidade construída lá atrás quando, em pleno vigor, entreviu a possibilidade de compor uma religião da natureza, trazendo à luz a esfera da experiência afeta ao mundo das pulsões e da seiva natural, esfera recalcada pelo teor unilateral e pela assepsia da ordem familiar. Nisso, fica selado um campo de consonância em que a palavra de André-narrador incorpora a visão daquele que vivia as tensões, a incerteza. Pode, portanto, figurar o mundo e buscar um estilo capaz de celebrar certos valores que marcavam a militância do jovem André na contestação à lei do pai. Isso não impede que persista a diferença de postura entre o jovem André e o narrador que recapitula a partir de um ponto em que ele já é suposto saber, pois já recolheu as lições do desenlace e pode colocar os traços persistentes de sensibilidade em nova perspectiva - em que a urgência do drama pesa menos do que a organização do passado disposta a oferecer um sentido. Não por acaso, se há, na lapidação do estilo, o senso claro de equilíbrio e maestria, uma arquitetura, isso não faz parte daquilo que o narrador partilha com o jovem inquieto que foi e sobre cuja experiência solicita a reflexão para se tornar, quem sabe, suportável.

As marcas de uma identidade que atravessa o tempo estão nesse ajuste feito pelo narrador entre a sensualidade de sempre e o zelo de agora, enquanto narra, por uma ordem estética rigorosa, capaz de sugerir um princípio transcendente a impregnar de sentido toda e qualquer experiência, uma ordem em que o encontro é comunhão, o conflito é danação - e tudo se move como atualização de um paradigma, com crescente inclinação para um senso de fatalidade. E tal senso não deve ser discutido apenas com essa referência à condição dupla de André; é preciso incluir outras perspectivas (vozes), em particular a da figura paterna, mais evidente, pois que é antagonista, porta-voz da ordem. A perspectiva do pai nunca, em verdade, se faz totalmente exterior a André, seja o rebelde exasperado diante do irmão Pedro, seja o narrador localizado no futuro. $\mathrm{O}$ mais decisivo nesse dialogismo não vem dessas passagens em que tal voz se faz ouvir de modo direto, quando se explicita na locução hierática, sentenciosa dos sermões do pai que André "transcreve" 
como parte das cenas que tinham tempo e lugar no cotidiano da família (o momento da refeição, o discurso à cabeceira da mesa), e que a narrativa insere no seu movimento de enunciação do texto, ora dominando um capítulo, ora retornando ao final para fechar o discurso de Lavoura arcaica. O que importa ressaltar aqui são os momentos em que a lei do pai ganha voz de forma indireta, incorporada nos discursos de André, como bem atesta a citação feita pelo narrador logo no início (a teoria da relação entre os olhos e o caráter), e como vemos também na palavra desafiante do jovem que, de maneira curiosa, internaliza a lei em sua forma de colocar o drama familiar. Mais de uma vez, na conversa no quarto de pensão, o seu diagnóstico corrobora as advertências do pai quanto aos excessos da paixão e ao derramamento dos afetos, cujas consequências funestas ele próprio assume na confissão a Pedro. E é notável o fato de que tal perspectiva (voz) seja confirmada pelo futuro André-narrador em sua forma de compor as recordações da casa.

Resumindo, a homogeneidade de fatura da narrativa faz de André (o que narra) um ponto de orquestração que filtra as outras vozes para compor um estilo, uma coerência de transposição-recordação na diversidade dos papéis e das situações. Resta, no entanto, a clara diferença entre a situação épica do narrador que recolhe todas as falas e as dispõe, não como quer, mas como exige o texto, e a situação dramática do jovem André que conversa com o irmão - situação que contamina, inclusive, suas pequenas narrações de episódios então recém-acontecidos. Seu alvo é o irmão; sabemos com quem e de onde está falando. Do mesmo modo, embora as transcrições dos sermões do pai sejam do controle de André-narrador, sabemos que se trata de uma voz que tem situação bem definida lá no passado, exceto quando se repete ao final, a título de homenagem, quando já não é fala dramática que tem lugar e audiência definida.

No dialogismo de Lavoura arcaica-livro, é mais sutil, mediada, a incorporação da perspectiva (voz) da mãe, que, enquanto "fala subterrânea”, espécie de “ambiente” legado pela tradição, afeta também as tensões do estilo, e o narrador reconhece seu papel decisivo na conformação dos valores e dos sentimentos.

Já observei que o filme, em sua multiplicidade de meios de expressão, amplia esse dialogismo, pois as vozes, em sentido estrito, interagem com outras matérias de expressão (corpos e gestos vêm compor um mundo de efeitos próprios, mesmo que se refiram a 
ações descritas no livro). O cineasta pode distribuir as "tarefas" e os efeitos pelos diferentes canais à disposição, podendo tornar mais discernível o que, no livro, se encontra amalgamado. Há aí liberdade e risco, pois que há interpretação. E muita coisa se altera nessa escuta do "grão das vozes", na relação entre a retórica das palavras e a dicção dos atores, incluído nesse jogo o timbre da voz over que narra.

$\mathrm{Na}$ ordenação dos registros da fala (o dramático e o épico), Luiz Fernando Carvalho introduz um dado novo: reforça a oposição entre a voz como peça do drama e a voz como evocação (à distância), oferecendo dois timbres distintos ao protagonista. Como agente dramático, ele traz a voz do ator Selton Melo, que dá corpo ao jovem André que vemos em cena (vez ou outra, também o ouvimos em voz over, quando o diálogo com o irmão sai da vista para que se mostre a ação imediatamente referida em sua fala). Como narrador futuro, o filme traz outra voz para André (que reconhecemos como a do diretor do filme, mas ela não precisa de tal reconhecimento para marcar sua diferença). Essa outra voz exibe uma tonalidade lírico-nostálgica que se projeta como uma dicção própria à elegia que, na evocação, se dirige a todos os que, no corpo dilacerado da família, viveram o seu momento trágico - valem aí os princípios da unidade familiar sancionada pela linhagem da tradição e pelo coração materno. A voz do narrador não se encarna, permanece fora do circuito dos corpos visíveis - como eu disse, é um outro André face ao que se encarna em Selton Melo. Ao não encontrar um corpo que lhe dê ancoragem, um lugar no espaço visível e no tempo representado, esta voz flutua, aproximando-se da música em seu efeito de envelope-sonoro, e encontra, assim, uma dimensão que é muito própria ao cinema em seus efeitos produzidos por esse tipo de locução em primeira pessoa. Cito Michel Chion:

O que poderia ser mais natural em um filme do que uma pessoa morta continuar a falar como voz sem corpo, flutuando na superfície da tela? No cinema, em particular, a voz desfruta desta proximidade com a alma, a sombra, o duplo - estas representações imateriais, destacáveis do corpo, que sobrevivem à sua morte e às vezes chegam a abandoná-lo ainda em vida. Quando não é a voz dos mortos, a narrativa em voz over é com frequência de alguém quase morto, de uma pessoa que completou sua vida e está apenas esperando a morte (CHION, 1999, p. 47). 
Adiante, especifico melhor como se pode ligar a figura de André e sua voz over com um sentimento singular que não está distante das observações de Chion. Por ora, vale lembrar o quanto o senso de proximidade dessa voz em nossa escuta se faz da tonalidade conseguida - emoção e discrição - , capaz de criar um fundo sereno que dialoga com as outras "vozes" que ora estão em sintonia com ela, ora se fazem mais dramáticas, tal como acontece com a música. Se o final do livro faz a referência ao grito visceral da mãe como depósito da tradição milenar na reação à catástrofe, o filme, embora não traga a figura da mãe ao centro naquele momento da verdade, distribui a presença da "voz" materna ao longo do processo, em particular no feitio reconciliado da dicção do narrador e no senso de recolhimento ou exaltação trazido pela música. Esta tem presença marcante na definição do significado de cada passagem tal como seria filtrada pelo polo sensível da tradição. Por essa razão, há situações em que há um nítido contraste entre o fundo sonoro e o que vemos de intensidade e de arrebatamento, indignação, no jovem André, cuja agitação não raro se acompanha de uma frase musical melancólica. O canto da tradição na linhagem materna ora é sensação de pertinência com uma confortante dimensão de abrigo, ora é expressão de dor, uma aflição atenta ao que há de ameaça, e não ao que haveria de aventura ou de promessa no gesto de revolta. Exaltação musical? Somente nas evocações da infância luminosa e na saudação ao momento em que se define a decisão de André pelo retorno: a imagem dos dois irmãos no trem (em si, nada radiosa) ganha vida e senso épico pela música. Não por acaso, a locução do narrador over silencia nessa sequência, tal como em outros momentos de euforia ou tristeza, pois sua tônica é a separação face ao tempo do drama e das reviravoltas, valendo mais em sua dicção o senso de uma "assimilação filosófica" do acontecido.

No filme, conflito e reconciliação correspondem, portanto, aos dois timbres (Selton Melo e Luiz Fernando), correlatos às duas velocidades de André, sempre articuladas aos outros influxos de imagem e som, valendo como caixa de ressonância, mas não como única voz, pois temos um efeito geral de contaminação próprio ao estilo indireto livre que abriga aqui todos os modos: o discurso da lei e o do afeto; o discurso da revolta, confuso e limitado, embora convicto de sua verdade; o discurso de uma vontade de poder, mais efetivo nas proclamações do jovem André onanista; enfim, o discurso da 
narração reconciliada. Em toda essa orquestração, permanece um traço fundamental: o concerto das vozes se tece em família, sem um ponto de vista externo.

\section{A religião de André}

André recebe a visita do irmão que começa a longa conversa trazendo o relato queixoso das dores da família: o desespero discreto da mãe; o silêncio obcecado de Ana; enfim, a perda de luz que a casa partilha com este André que virou um enigma para eles, ao partir sem explicações, num momento em que seus motivos eram um segredo dividido apenas com Ana. O diálogo sobre o sentido de seu exílio dá ensejo ao retrospecto. O tom de André diante do irmão é de desafio, pontuado de ataques à ordem familiar; no entanto, o impulso de trazer a verdade tem seu lado de confissão, necessidade de desvelar, sem cálculos ou subterfúgios, fazer da escuta de Pedro o momento de um ajuste de contas com a sua própria história que, uma vez chegada a termo, sela a decisão pelo retorno à casa, que se abre para incertos desfechos.

A cena na pensão é uma longa sessão expiatória em que Pedro se divide entre a palavra da lei (frequente) e os lances de afeto (raros), no que se revela mais um episódio do jogo familiar assentado na ambivalência das palavras e dos gestos, a criar um campo de forças em que o tocar o outro expressa demandas contraditórias, uma ambiguidade constitutiva que a lei do pai não pode admitir, mas que está lá como conteúdo de experiência que pode se tornar trágico quando vivido na forma do excesso, compondo assim o que uma expressão do narrador do livro enuncia como a "geometria barroca do destino" (barroca porque impressa na constelação de gestos e afetos contraditórios).

A resistência inicial de André à demanda fraterna ganha, de início, a forma de uma ostentação orgulhosa de sua verdade como "ovelha negra" da família e de uma diatribe contra a autoridade do pai; no entanto, sua fala não exclui a admissão de culpa e a colocação do polo materno como origem do problema. Quando nega que a ameaça à unidade da família tenha se instalado com sua saída, ele afirma que a desunião havia começado muito antes, com o afeto da mãe, com os seus excessos, matriz de uma sensualidade exagerada 
que minava a lei do pai. É fundamental essa admissão, pois, já na conversa da pensão, André atribui a sua desdita a uma trama do mundo em que os dois polos - o do afeto e o da lei - se põem como corresponsáveis. Tal visão - posta à tona nas provocações do rebelde atormentado - se fará diagnóstico sereno na voz do André narrador perto do final do romance, quando ele descreve a dualidade trágica dos dois ramos da família expressa no modo como se dispõem à mesa: à esquerda do pai, a ala dos que se perdem no mimo da mãe, o afeto a "corromper" os filhos; à direita, a obediência e a continuidade da lei. À esquerda do pai, a linhagem da mãe, composta por ela própria, por André, Ana e Lula, "trazia o estigma de uma cicatriz", "um enxerto junto ao tronco talvez funesto, pela carga de afeto"; à direita, os filhos afinados à lei se apresentavam como um "desenvolvimento espontâneo do tronco".

No filme, há uma alteração na ordem das sequências, pois tal cena e tal sentença estão montadas logo após a imagem do título Lavoura arcaica em fundo branco, ou seja, bem perto do segmento de abertura que comentei. Ao que parece, também nesse caso o cineasta preferiu orientar o espectador, fazendo desde logo presente o plano-emblema em que o espaço da sala de jantar e o comentário do narrador expõem a ordem familiar. Em contraste com o pai sentado na cabeceira da mesa, a mãe é já parte daqueles sob tutela, sentada num dos bancos laterais, ao lado de André e dos outros, para compor a imagem simétrica que, em verdade, é a imagem da oposição que desestabiliza o poder instituído. Com a antecipação dessa imagem, ele pode trabalhar a força simbólica do espaço e dessa disposição das figuras no ritual do pão diário, projetando seus efeitos ao longo do filme, marcando a evolução das coisas na família pelo que se mostra da mesa sendo desfeita, ou da sala vazia, de modo a compor visualmente o elo de união entre o que se passa nesse espaço e o que se associa, numa das muitas formulações, à proibição do incesto: "On ne s'accouple pas avec ceux qui mangent dans le même bol et la même assiette".

A conexão entre o leito e a figura materna - no encantamento da infância - é o outro polo desse jogo de símbolos em que cama e mesa sinalizam valores, assim como certos deslocamentos, notadamente na atividade sexual de André sempre ao rés do chão, seja na casa velha em que deflora Ana, seja nas cenas dele sozinho na mata, ou mesmo no quarto de pensão onde se masturba deitado no 
assoalho e, como sempre, de pés nus.

Desenham-se, na conversa com o irmão e nos flashbacks, as duas fases do confronto. No plano mais imediato, temos um protagonista que, apesar dos impulsos de transgressão, está débil e às vezes hesitante diante de Pedro, em nada à altura da fase anterior, quando parecia soberano na proclamação de sua condição livre, quando o instituir uma nova lei era o grande projeto, uma lei que incluísse a posse de Ana. ${ }^{4}$ Lá, prevalecia a sua fé na potência do indivíduo que, desafiando o "está escrito" da tradição, afirmava a sua autonomia de maneira hiperbólica: "Eu quero ser o profeta de minha própria história".

Essa foi a sentença de autocriação que ele pronunciou quando imerso no que, ao longo do filme, se põe como a vegetação exuberante da fazenda, esse espaço do culto a si mesmo que, passo a passo, selou o isolamento de André na comunhão com a natureza e na consagração do enlace com o mundo animal. Era o prazer cotidiano de esconder-se na mata e esfregar-se na terra, cobrir-se de folhas, umedecer a pele nos musgos e na água barrenta, salpicála de insetos e de tudo o que constituía os paramentos da sua religião do "ser natural". Religião cujo princípio de "gratificação já" deu ensejo ao momento maior - o da cópula com Ana, a deusa que veio completar a sua liturgia. Ana foi a "presa" que, no plano da nova lei, se faria o princípio do mundo; esse de que o corpo de André podia dispor com sua sensualidade polimorfa, que incluía a palavra proferida - o texto - , pois a onipotência do pensamento alcançava aí o momento pleno em que era sexualização do pensamento. O jovem André faz lembrar a formulação de André Green: o narcisismo compõe uma religião, mais do que uma estética. Dimensão que o texto e o filme transfiguram em estilo (GREEN, 1988, p. 46 e 58 ).

$\mathrm{Na}$ evocação de seus rituais do passado, o esforço de André na pensão é colocar Pedro em confronto com a verdade do corpo e suas demandas, convencê-lo da inconsistência do sermão do pai contra o qual, mais do que desfilar argumentos, ele se põe, ele próprio e sua ação, como argumento, calçado na sua autoimagem como paria, figura condenada pela verdade que teve coragem de encarar. Há nele um cultivo da exclusão, que é uma espécie de revanche face ao jogo de esconde-esconde que sempre o cercou. Como diz ao irmão, somente ele testemunhou os humores da família, cada grito do corpo, cada inquietude impressa no conteúdo do cesto de
4. Uso aqui o termo "instituir uma lei”, ou seja, a própria lei, a partir de sugestão de Glacy Queirós de Roure (PUC-Goiás). Em debate por ocasião de uma palestra minha no Festival Internacional de Cinema Ambiental, na cidade de Goiás, Glacy Queiroz observou haver, no caso, uma neutralização da lei do pai pela obstrução materna, o que impediria tal lei de alcançar efetividade; desse vazio, se faria o impulso legislador de André 
roupa suja, e só ele sorveu o vinho necessário ao culto do obsceno e mergulhou fundo nos prazeres do bordel. Nele, as moças lhe deram presentes - a liga, a pulseira, a renda manchada - , nos quais se depositou uma história de impurezas que ele, no entanto, coleciona e faz questão de mostrar a Pedro.

Há, nas provocações de André, esse pendor para a exibição de peças, para a fala incisiva que pode chegar à insolência ou se reduzir a uma queixa; de qualquer modo, sempre teatral na sua ênfase, traço que o filme faz questão de ressaltar, na performance do ator e na luz expressionista da pensão (o mesmo acontecerá na cena da capela, em seu monólogo diante de Ana). André faz crescente a presença do vinho, a despeito da reprimenda de Pedro, a que ele responde, a certa altura, com um gesto enfático de exaltação do excesso, gesto que encontrará eco na forma como Ana erguerá o braço para derramar o líquido no próprio corpo na sua dança provocativa ao final.

Será de Ana o teatro mais consequente, como expressão do "demônio no corpo", mas já aqui, na conversa da pensão, há o momento exaltado em que André proclama: "Sou epilético". E imagina a família a gritar: "Tem o demônio no corpo" - numa sequência em que o coro de mulheres de preto, numa procissão doméstica de caráter expiatório, traduz em imagem a imprecação de André, num cenário em que pipocam as imagens dos rituais de defesa diante do possuído. Nesse momento, retorna aquela convulsão própria à cena da masturbação; ouvimos o barulho do trem, mais breve, no conjunto das associações que reiteram a condenação a ele dirigida; ele, o portador da peste, não no sentido literal da doença física, mas no de uma entidade psíquica "em estreita relação com o que chamamos de fatalidade" (a expressão é de Artaud, 1999).

A peste é a figura da crise radical que André assume como atitude heróica frente ao destino. No entanto, a força do delírio depende da crença, e essa alquimia foi abalada desde a rejeição de Ana, o que limita o vigor de sua performance. Seu pequeno teatro da crueldade se volta para a exibição do recalcado, disposto a fascinar, liberar disposições inconscientes, numa cerimônia em que toda a ação visa tocar o nervo de sua audiência, reduzida a Pedro como representante da família. Porém ele já está longe do que sua a religião da natureza prometia. Em vez da alquimia do gesto, do adensamento da figura do maldito, é a sua crescente entrega e a sua decisão de retorno que prevalecem. Retorno em que haverá o momento de uma ambígua 
acareação com a lei do pai, o anúncio de uma radiosa manhã que, em verdade, consumará o desastre, uma tragédia na qual ele já terá saído do centro, porque o sujeito da ação, a imantação do teatro, a figura-peste será Ana, que - sem palavras, na linguagem do corpo - virá a consumar um teatro mais vigoroso, apto a abrir os abscessos da família.

Na provocação de André dirigida a Pedro já se insinua uma fissura de que as relíquias do bordel trazem o sinal, pois condensam o que uma sequência do filme encena como uma zona de sombra do desejo vivido na "longa adolescência". A relação angustiada com o mundo fora da casa, confirmada em tudo no seu caminho, chega a seu termo final no espaço lúgubre da pensão. Por que esse zelo com as peças de tal coleção? Cuidados de um memorialista? Expressão de sua visada religiosa da sexualidade, que requer seus paramentos? Que endereço teriam os paramentos como parte dessa parca bagagem de um André que não acumulou riquezas, não viveu prodigalidades, não abraçou o mundo como aventura, nem mesmo esse mundo sinalizado pelas relíquias?

Não tarda, e sua vontade de agressão faz tais objetos de cena encontrarem um sentido. Com sarcasmo, sugere ao irmão que leve os adereços e os entregue às irmãs, para que aprendam as virtudes da sensualidade e do fetiche, abandonem o recato e a modéstia. A provocação vale como uma premonição, pois antecipa o final, faz da coleção o instrumento maior de um jogo contraditório, assumido aqui no plano da fantasia envenenada, mas confirmado lá pela ação espetacular de Ana, que vem dançar à vista de todos, portando o conteúdo da caixa que André insistiu em levar consigo. Ela mistura o que a lei quer separar, veste a família com os signos do bordel, condensa no corpo regado a vinho e no brilho das jóias baratas, ou seja, nos objetos de cena, a referida geometria do destino. Estaria aí um traço barroco da inflexão trágica do gesto de Ana, se aceitarmos a observação de Walter Benjamin (1984) quanto à importância dos objetos de cena no que ele examina como "drama barroco" (para distinguir da tragédia clássica).

\section{Versões da crise: a loquacidade do melodrama e o silêncio da tragédia}

No livro, há um breve capítulo em que o narrador se refere à sentença repetida do avô: "Está escrito" (cujo valor é sugestivo na ordem 
geral das coisas). No filme, tal fala ocorre num plano que evoca a figura do avô a observar o relógio no corredor da casa, plano inserido no fluxo de uma montagem que faz a sentença repercutir sobre a imagem de Ana e André, infantes, seguida de associações que nos fazem saltar aos dois irmãos já adultos, em plena chuva, a cruzar seus olhares investidos de desejo. A ordem profética (do avô) se projeta sobre a dupla, numa articulação precisa em sua sugestão de fatalidade, sem paralelo no livro.

Posto em cena o desejo, a revelação do instante feliz do incesto só se dá no último terço de Lavoura arcaica, depois de longa preparação, como se fosse necessário o compasso de uma liturgia para relatar a experiência que "estava escrita" e se teceu pelos ardis do tempo, como que para confirmar um paradigma da experiência humana (isolada, a família ganha o sentido de uma alegoria, microcosmo que almeja sentido universal).

"Era Ana, era Ana, Pedro, era Ana a minha fome." São as palavras de André na pensão. Anunciado o momento, não tarda a vir o dia ensolarado em que seu olhar na casa abandonada, em ruínas, define os termos da entrega de Ana. A sequência se abre com a pesquisa de André na casa velha, sua forma de examinar texturas e olhar as frestas deixadas pelas tábuas em decomposição. Há um toque de voyeurismo que terá como horizonte final o corpo de Ana, que avança de forma gradual, sugerindo nesse espaço um senso de revelação, antes que o encontro se dê. André intui a feição especial do cenário, vê aí um tempo condensado e reflete sobre o instante da transposição (que marca a passagem sem retorno), enquanto brinca com a matéria que os anos depositaram nas paredes e no chão. $\mathrm{O}$ motivo das mãos crispadas se descontrai para significar o diálogo suave com a casa, um tirar a poeira com as unhas, fazer a marca, algo em sintonia ao que faz com os pés em suas fricções usuais. Num certo momento mais eufórico, chuta o terreno de modo a levantar a palha, tornar palpável o sol nesses flocos em suspensão que coroam um movimento armado pela música e pelo pensamento (voz over), nessa hora de promessas que contrasta com outros momentos em que a fluidez (da fumaça, por exemplo) será a imagem associada a uma reflexão mais sombria sobre a experiência.

Na sequência do encontro com Ana, temos a manifestação mais decisiva da passagem da luz à sombra, o contraste entre intensidades - a claridade do sol, o sombreado das velas - como um 
motivo central no filme. Quando, na casa velha, André percebe a presença de Ana a cumprir os seus desígnios, a luz parece celebrar a beleza da união e sua legitimidade. Dono do cerimonial, André solta a voz e impregna a cena de sentidos, encena o pacto com Deus como que para ressuscitar a irmã inerte na palha e faz desse suposto sopro de vida nascido de suas palavras um motivo maior de euforia. O encontro com Ana é vivido na chave da posse, associado à cena do menino que aprisiona a pomba e proclama feliz: "É minha". $\mathrm{Na}$ repetição do momento da infância, ele agradece o milagre. Vê o Tempo a legitimar a posse; sua paixão parece abençoada. O mundo vela por seus desejos - ele dorme. Quando acorda, porém, não demora a descobrir que o amor exige a vigília. Ana não está ao seu lado. Invertem-se os valores, e tudo é sombra quando ele a procura; só a encontra na capela, a rezar, arrependida. Eufórico, sem vê-la de verdade, ele expõe as bondosas promessas engendradas na felicidade, mas a constatação gradual do descompasso azeda tudo. A fala dele muda de tom. Explorando a vantagem da separação das vozes (de Selton Mello e Luiz Fernando), o filme confirma, na dicção e no gesto do ator, o estilo histérico do personagem no momento da onipotência ameaçada, quando o silêncio de Ana corta a sua felicidade. Chorosa, incapaz de falar, ela é a figura do trauma. Ele, em plena fúria, declara guerra ao mundo, roga suas pragas, assume o enjeitado. Passando do êxtase da união à agonia, resume a sua postura diante do mundo: "Eu não tenho culpa", repete várias vezes. E lança a palavra de vingança: "Não tive meu contento, o mundo não terá a minha misericórdia".

Esta sequência da capela é decisiva. A agitação, as contorções do corpo, a tonalidade da voz, as mãos por dentro da calça a alcançar o sexo (eco da cena de abertura) explicitam a absoluta ausência de mediação na demanda do jovem André. Autocentrado, ele assume o melodrama, o discurso da vítima exaltada. Quer tudo, não aceita recusas. Será cordato e conciliatório, se antes vier sua satisfação maior; do contrário, será rancoroso e vingativo. Como resolver essa equação sem a cumplicidade de Ana? Como permanecer no território da família com esse projeto de uma vida em segredo?

Diante do impasse, vai-se embora, ressentido com as duas alas da família (conforme a disposição à mesa). Fora de casa, porém, não tem projeto, pois aderiu ao princípio da autarquia familiar enunciado pelo pai. O que este sempre afirmou na esfera do dever, como 
5. Menciono a questão do incesto irmão-irmã como utopia política, não em abstrato, mas porque isso é posto em foco por Lydia Flem-Olender no ensaio "D’Oedipe à Figaro: une mise en scène de l'inceste", incluído em Claudie Danziger (Org.), Violence de familles: maladie d'amour (Paris,

Éditions Autrement - Collection Mutations, n.168, 1997). A autora faz referência a um imaginário burguês

(século XVIII) em que a ruptura da ordem familiar ganhava essa dimensão política de afirmação do indivíduo numa nova sociedade. expressão de uma ética do trabalho, André desloca para a esfera do desejo: que tudo se resolva "em família", como ele mesmo explica a Ana quando aposta tudo na união que ajusta o princípio da autarquia ao seu curioso pansexualismo. Ao incorporar o princípio da autarquia como um valor, ele molda a palavra do pai segundo o seu apetite; desloca o sentido da "lavoura" (a imagem do arado é inserida na sequência da união sexual dos irmãos). Para André, tal lavoura se desdobra na utopia endogâmica que ele descreve ao fazer o elogio da família que se basta, deslocando os termos da filosofia do tempo exposta pelo pai.

Essa forma peculiar de desvio da norma não consegue, entretanto, vingar. A ruptura, nos termos em que se faz, permanece sem horizonte, uma vez que a trama de Lavoura arcaica não supõe o incesto como instauração de uma outra ordem. A que André propõe se mostra frágil demais, um desafio acima daquele que a encarna. Não se trata aí do incesto como utopia política referida a um contexto social, afirmação do indivíduo contra tradições de classe. ${ }^{5}$ Ilhado, esse laboratório voltado para uma libido familiar autárquica se revela uma tragédia; será confirmação, em ato, de uma lógica da experiência em que prevalecem o preceito da tradição, a instauração da culpa, a precipitação do desastre.

A religião de André ignora o princípio de realidade do trabalho ou, pelo menos, quer rever os seus termos. O seu Tempo é o da "gratificação já”, como um direito natural. Não se trata de hedonismo ou do elogio a um estado de letargia ociosa, mas de uma inversão. Antes, a dádiva; depois, o suor. Ele recusa, portanto, um Tempo feito de renúncias e adiamentos, em que a virtude maior é a paciência na espera pela recompensa que o patriarca oferecerá em troca do bom proceder e da "aceitação do jogo", como bem demonstra o teatro da contenção do apetite encenado pelo pai na parábola do faminto que André tanto odeia. É preciso reivindicar os direitos da impaciência.

Rebelde, transgressor, ele tropeça nessa disputa de território com o pai dentro da própria autarquia e não vê o mundo exterior senão como espaço de fuga, deriva, diante do qual se mostra inapetente, sem forças. O destino de André é o oposto do encontrado, por exemplo, pelo protagonista de Pai, patrão (dos Irmãos Taviani), que, na busca de identidade e recusa da ordem paterna, desloca tal busca para outras esferas, fazendo a passagem da família para a 
sociedade e para a nação, compondo uma parábola de conquista de cidadania, platô de onde pode voltar para fazer a narração - misto de reflexão crítica e elegia - dos tempos da solidão na montanha. André-narrador não tem essa prerrogativa, pois fala como um sobrevivente sem outra referência que não a da própria família destroçada. No seu caso, o movimento se fez em círculo, definindo um retorno à casa de mãos vazias, que se associa ao perfil da parábola bíblica. Lá, o filho pródigo reclama sua parte na herança em nome de um impulso de aventura no mundo exterior, visto como promessa. Aqui, André reclama sua parte do patrimônio familiar naquela forma que reforça a sua fixação na terra, não o abandono, pois o que quer esteve ali desde o começo: o corpo de Ana. A recusa da ordem paterna é projeto de liberdade a ser vivido na zona de sombra dessa mesma ordem, não fora dela ou esquecendo-se dela.

Se a aventura, na parábola bíblica, se mostra ilusória, transformando a prodigalidade em desastre e consagrando o abrigo familiar em oposição às atrações do mundo, aqui a catástrofe no retorno está assentada na instabilidade desse abrigo, a despeito da boa recepção do pai, pois logo será revelada a transgressão que deu ensejo à partida do filho. O que se engendra em casa se resolve em casa, ou se destrói em casa. O único influxo externo que afeta a fazenda é aquele condensado na mala de André, que colecionou as relíquias do bordel - que terão papel fundamental na explosão da crise. No mais, vale a experiência da autarquia, assumida aqui de forma mais radical do que em outras encenações da vida em família. Nesse sentido, o desastre se dá como expressão direta do embate entre individuação e tradição, lei e desejo, sem buscar assento em coordenadas históricas a que se referiria a experiência da família. Sim, há o fato da migração, que dá ressonância a essa dimensão de isolamento (a festa maior no bosque, comandada pelo pai, é homogênea em sua composição) e explicita a origem árabe-mediterrânea dos códigos de cultura vigentes na autarquia, mas estes últimos estão lá sem nenhum sinal de que a questão seja o seu desgaste produzido por algo de específico ao novo contexto. O tempo da crise é autorreferido, interno à dinâmica familiar, uma irrupção abrupta, não o resultado de uma evolução (ou decadência) gradual mensurável em termos do tempo social. ${ }^{6}$

Há casos em que, ressalvada a natureza sexual do drama, constrói-se um quadro histórico que permite a caracterização do colapso
6. Em termos de uma autofagia familiar, vale aqui a referência a Álbum de família, de Nelson Rodrigues, em que há a reiteração obsessiva do motivo do incesto e o tema do retorno dos filhos à casa como o momento em que se precipita a crise. A trama - lá, mais folhetinesca - destrói um núcleo familiar incapaz de administrar o que os próprios personagens proclamam como sua libido desenfreada, espécie de cio coletivo bem distinto da dinâmica e do tom mais elevado encontrados em Lavoura arcaica, em que é mais radical a implicação do isolamento no caminho que leva à ruptura trágica. Se há, portanto, esse elemento comum - a libido - como força impulsionadora do trágico, como acontece em muitos dramas do gênero, e também a sugestão de um desejo de autarquia num dos membros da família, há a enorme diferença de tratamento, de perspectiva e de estilo. 
como decadência, incapacidade de reprodução dos valores da família a partir de suas tensões com um contexto de onde vêm os dados novos, que precipitam o fim de seu mundo já desgastado, onde tudo é fardo, neuroses obsessivas, não orgulho ou inspiração, na relação com o passado. Em Crônica da casa assassinada, de Lúcio Cardoso, assim se constrói a tragédia dos Menezes. Há um esgotamento assumido que se expressa numa morbidez disseminada e nas manias, não faltando o motivo central do incesto e seus correlatos rodriguianos: a rivalidade entre irmãos, a frustração e o ressentimento. Mas tudo aí se precipita pela chegada de uma figura externa, a jovem Nina, espécie de anjo exterminador que fascina todos na Casa. Em Lavoura arcaica, ao contrário, prevalece a teia sutil dos processos “em família”. Não é preciso a mulher trazida do Rio de Janeiro para romper de vez a ordem da fazenda; a força motora vem da própria imantação presente nesse mundo em pleno vigor ("quanto mais estruturada, mais violento o baque, a força e a alegria de uma família assim podem desaparecer com um único golpe"). É tal imantação que provoca o retorno do filho que em nenhum momento vivera sua travessia "para além das divisas do pai”, como promessa.

No retorno de André, a recepção do pai, as súplicas da mãe e o enigma de Ana agem sobre um filho rebelde que chega debilitado, pois não recolheu forças nem argumentos em sua viagem. Não surpreende que seja incapaz de sustentar a postura afirmativa até o fim no seu confronto com o pai. Há coragem, resistência, mas o impulso de um "não" mais incisivo se dilui no longo torneio de palavras que repõe o impasse e o coloca em registro de baixa potência, preparando a inércia que vai obscurecer sua percepção da tragédia quando Ana assumir o gesto radical. Após transgressão e exílio voluntário, ele retorna para um enfrentamento em que não consegue fazer prevalecer o seu ponto de vista, pois o saber tácito da tradição ganha mais força (não propriamente mais razão) num debate em que ele se enfraquece porque sua argumentação é sensível aos dois lados de cada questão e porque, sobre os contendores, se depositam o olhar aflito e, por vezes, o sussurro da mãe. Considerado o exclusivo andamento do simpósio, André não ultrapassa o limite da ordem, embora a questione, e o pai, para uso próprio, interpreta o que é complexidade vinda da natureza das coisas - o amor sufoca, a palavra não tem o sentido que aparenta, a ordem contém em si a desordem - como confusão vinda da psicologia e da falta de hom- 
bridade do filho. O que termina por manter o impasse, que ganha a aparência de um acordo possível, ensejando as homenagens ao retornado que talvez confirmassem o que o próprio André vislumbrou como ocasião de júbilo, não fora o gesto de Ana a explodir as tensões acumuladas.

André chamou a si a tragédia ao encarnar a unidade dos opostos (o princípio da autarquia e o desejo sem limite); no entanto, quando se deflagra a ira do pai, essa ira o encontra em plena apatia, numa morte simbólica que diz sim ao que seu princípio de soberania individual negava. Há aí a transformação de um princípio em seu contrário - dialética do trágico, sem dúvida. Mas no instante crítico ele já não é o herói na ação, reduzido à posição de um observador entorpecido. Na manhã da festa de seu retorno, Ana será a protagonista.

O André narrador afirma não ter visto com clareza o instante da violência, pois voltara à antiga posição de voyeur fora do círculo, como quem, no fundo, não retornou para o confronto e para a verdade, mas para a ilusão da volta a um passado irrecuperável. O sonho do paraíso perdido revela-se o pior dos sonhos, e o mais sinistro. A contradição de André entrega a irmã ao ressentimento do irmão; ele que, na primeira cena da festa familiar, havíamos observado a dançar com ela, e que agora, ferido pela imagem da irmã e sua feição dionisíaca, vem destilar a verdade dos irmãos no ouvido do pai. ${ }^{7}$

O sacrifício de Ana precipita o que a hesitação de um André dividido deixara para as circunstâncias. Cortando qualquer anelo de retorno à vida familiar de outrora, ela se dá em espetáculo como figura da transgressão quando André a quer em segredo, a partilhar uma anomalia clandestina aninhada na ordem do pai. ${ }^{8}$

Inserida na economia simbólica do trágico, tal como a desenha Lavoura arcaica, a catarse de Ana transfigura o ciúme, a vingança, a solidão e o desespero. E é dessa mescla de sentimentos que ela colhe a energia que se converte na cólera do pai. Negando o que fora sua divisa maior - o perdão e a paciência - a lei vive nesse instante sua verdade maior: a violência. Dela, é Ana o alvo, e não André, que se enterra em silêncio depois de olhar o rosto decomposto do pai, que, perdido, compõe a feição patética do mundo de clareza que pensava encarnar. Ao receber o golpe, a filha confirma sua determinação curtida no silêncio, por longo tempo, em franco contraste com a loquacidade melodramática do irmão. O momento
7. Não está explícito no livro o que o irmão disse ao pai na hora decisiva, embora não seja difícil para André nos legar a sua inferência. O filme opta por explicitar, repondo na tela a imagem do incesto, os planos de André e Ana deitados na palha, o beijo.

8. É interessante que Lula, o caçula, tenha o encontro, em seu próprio leito, com o irmão retornado. Nessa cena, em que a penumbra sugere o erotismo do toque e dos pés descalços de André, Lula deixa claro seu desejo de ser mais efetivo na ruptura com a família. Mais afirmativo no interesse pelo mundo, Lula critica o retorno de André como um fracasso e anuncia seu projeto de um abandono mais consequente do território familiar. 
decisivo, portanto, é o da dissonância sem palavras. A dança - antes linguagem da comunhão familiar quando conduzida nos limites da graça e do recato - muda agora de sinal para tornar-se a afirmação total da libido, que, ela sabe, compõe o escândalo irremediável. Ressoa em sua performance a sugestão de Artaud (1999): Eros é uma crueldade, pois que vida em sua feição impositiva, a assumir as consequências.

\section{A pulsão de morte de Narciso, a planta}

Havia na abertura do filme, no quarto de pensão, a atmosfera sombria. No primeiro flashback, houve o recuo à infância, aquele tempo ensolarado do esgueirar-se na mata e cobrir-se de folhas, ouvindo o chamado da mãe e das irmãs sob aquela luz que o olhar de André para o céu anunciava como promessa. Em seu último lance, o filme introduz uma cena de repetição ausente no livro. Retoma o corpo deitado e faz retornar o plano da copa das árvores. Este último ganha, no retrospecto, o sentido do nascimento e a dificuldade de aceitá-lo. Prevalecem, no desenlace, a prostração de André e sua nostalgia uterina, o entregar-se ao leito natural.

9. Vale citar uma observação de

Depois da tempestade, ele se isola no bosque, como muitas veJacques Lacan sobre a questão: "Todo

o regresso, seja ele parcial, a estas seguranças [familiares] pode fazer iniciar no psiquismo ruínas sem proporção com o benefício prático deste regresso. Todo o acabamento da personalidade exige este novo desmame. Hegel formula que o indivíduo que não luta para ser reconhecido fora do grupo familiar não chega jamais à personalidade antes da morte... No que diz respeito à dignidade pessoal, não é senão no plano das entidades nominais que a família promove o indivíduo e não o pode fazer senão à hora da sepultura”. Ver Jacques Lacan, A família (Lisboa, Assírio \& Alvim Cooperativa Editora e Livreira, 1987), p. 33-34. zes no passado, e retoma o motivo da venda nos olhos, que lembra o gesto da mãe nos bons tempos. Enraizado, tal como uma planta, não abandona o território, e o cobrir-se de folhas torna-se agora um fechar as portas do mundo. A submersão - sendo dele o ponto de vista - se desdobra na tela preta, derradeiro torneio da imagem. O filme sela aqui, nesse torneio regressivo do gesto de André, o seu discurso sobre a ambivalência da luz - promessa, quando "na medida", ou ameaça, quando em excesso - instituído pela voz do pai, dentro da pauta de valores em torno da qual o filho teceu sua revolta. $\mathrm{O}$ travo terminou por dar lugar à dicção do ressentimento, e ela se fez nítida no tom da fala de Selton Melo em certos confrontos, projetando uma afetação de menino mimado sobre o seu grito de liberdade, o que reduziu a força do seu impulso de autonomia. Descartado o salto para o mundo, resta a fixação no solo materno.

Quando a família é o Todo, não há desmame. ${ }^{9}$ Morre, portanto, André como expressão contraditória do princípio da autarquia. Pela palavra, sobrevive André como voz sem corpo a nos conduzir em 
seu movimento por sobre as imagens. Narrador enlutado, ele reconhece a astúcia da trama em que a culpa é repartida entre todos, o polo masculino e o feminino, incapazes de se ajustar na proporção que daria ensejo à reprodução da boa ordem. Ambos foram radicais, cada um a seu modo, na afirmação de seus princípios. Posto que a mediação se tornou impossível, coube a André inventar a sua própria lei, fatal porque se fez um recuo em abismo ao próprio seio da família. Resta agora, a ele, ou a seu duplo, no tom de uma elegia, insinuar o mote da tradição: estava escrito. No último torneio, ele cede a palavra ao pai, como se o movimento do réquiem familiar, trazendo uma compreensão superior das razões de cada um, implicasse nesse auscultar de novo a ordem do Tempo - que cabe a Raul Cortez, pela última vez, enunciar, com a tela escura. No estratagema do filme, tal repetição crepuscular, embora traga a aura de um saber contemplativo, universal, seguro de si, é barroca em sua natureza, exibindo a ambivalência dessa mania sentenciosa do pai, que, ao opor uma regularidade natural das coisas ao desequilíbrio trágico, deixa entrever, no terno conselho da experiência, a palavra empenhada do poder. 


\section{Referências}

ARTAUD, A. O teatro e seu duplo. São Paulo: Martins Fontes, 1999.

BENJAMIN, W. A origem do drama barroco alemão. São Paulo:

Brasiliense, 1984.

CHION, M. The voice in cinema. New York: Columbia University Press, 1999.

GREEN, A. Narcisismo de vida, narcisismo de morte. São Paulo: Escuta, 1988.

KOZLOFF, S. Invisible storytellers: voice over narration in American fiction film. Berkeley: University of California Press, 1988.

NASSAR, R. Lavoura arcaica. São Paulo: Companhia das Letras, 1975. 